DOI: $10.14451 / 2.149 .7$

\title{
ПРАВОВАЯ КОЛЛИЗИЯ ФЗ «ОБ ОБРАЗОВАНИИ» И КОНСТИТУЦИИ РФ
}

\author{
(c) 2020 Дакашев Магомед-Эми Жабраилович \\ начальник отдела государственной службы и кадров \\ Администрации Главы и Правительства Чеченской Республики
}

() 2020 Ибрагимов Юсуп Муслимович

ассистент

Чеченский государственный университет, Чеченская Респ., Грозный

E-mailyusuf_ibr@mail.ru

В статье изучается образование, как неотъемлемый процесс воспитания и обучения. Рассматривается необходимость регулирования образовательной деятельности, на основании Ф3 «Об образовании в Российской Федерации», и Конституции Российской Федерации.

В заключительной части данного исследования делается акцент на то, что получение основного и общего образования на территории Российской Федерации, не может противоречить нормам Конституции Российской Федерации и приведение Ф3 «Об образовании в Российской Федерации» в соответствии с Конституцией Российской Федерацией.

Ключевые слова: коллизия, образование, Конституция РФ, ФЗ «Об образовании в Российской Федерацциџ».

Образование в соответствии со статьей 2 Федерального закона от 29 декабря 2012 года № $273-Ф 3$ «Об образовании в Российской Федерации» (далее - Федеральный закон «Об образовании в Российской Федерации») понимается как единый целенаправленный процесс воспитания и обучения, являющийся общественно значимым благом и осуществляемый в интересах человека, семьи, общества и государства, а также совокупность приобретаемых знаний, умений, навыков, ценностных установок, опыта деятельности и компетенции определенных объемов и сложности в целях интеллектуального, духовно-нравственного, творческого, физического и (или) профессионального развития человека, удовлетворения его образовательных потребностей и интересов [2].

Статья 29 Конституции Российской Федерации (далее - Конституция) закрепляет права граждан Российской Федерации в области образования.

Конституционное закрепление основополагающего правомочия как образование, является достижением гуманистической, социальной, культурной целей развития государства как института социального общества.

Кроме того, выделение данного правомочия в отдельную норму в основополагающем законе государства является важнейшей предпосылкой экономического, политического, социального,

культурного и правового развития общества и становления гражданского общества в государстве.

Вместе с тем, в некоторых случаях регулирование образовательной деятельности в социальной политике государства в процессе реализации фундаментальных задач и основополагающих целей, вступает в противоречие регулирующих норм в нормативных правовых актах различной юридической иерархии.

Пункт 3 статьи 29 Конституции устанавливает, что основное общее образование обязательно [1].

Исходя из смысла приведенной выше формально определенной правовой нормы, следует, что каждый гражданин Российской Федерации не достигший 18 лет обязан получить основное общее образование, иными словами получить аттестат об окончании 9 классов образовательной организации.

Однако, в соответствии с частью 5 статьи 66 Федерального закона «Об образовании в Российской Федерации» начальное общее образование, основное общее образование, среднее общее образование являются обязательными уровнями образования [2].

С учетом изложенного, отображается правовая коллизия несоответствия федерального законодательства Конституции Российской Федерации. 
В соответствии с частью 1 статьи 15 основного закона Российской Федерации, Конституция имеет высшую юридическую силу, прямое действие и применяется на всей территории Российской Федерации. Законы и иные правовые акты, принимаемые в Российской Федерации, не должны противоречить Конституции [1].

С учетом обыденного толкования части 1 статьи 15 Конституции отображается, что правовая норма Федерального закона «Об образовании в Российской Федерации», закрепляющего императивную обязанность гражданам Российской Федерации в получении среднего общего образования, не может применяться в противоречии с нормой Конституции.

Часть 1 статьи 15 Конституции Российской Федерации закрепляет прямое действие Конституции Российской Федерации на всей территории Российской Федерации, то есть обозначает позицию государства в прецедентной сфере российской правовой системы, в контексте основополагающего значения в применении правовых норм Конституции над правовыми нормами иных нормативных правовых актов.

Пункт 2 постановления Пленума Верховного суда Российской Федерации от 31 октября 1995 года № 8 «О некоторых вопросах применения судами Конституции Российской Федерации при осуществлении правосудия» устанавливает, что согласно части 1 статьи 15 Конституции, Конституция имеет высшую юридическую силу, прямое действие и применяется на всей территории Российской Федерации [3].

В соответствии с этим конституционным положением судам при рассмотрении дел следует оценивать содержание закона или иного нормативного правового акта, регулирующего рассматриваемые судом правоотношения, и во всех необходимых случаях применять Конституцию в качестве акта прямого действия.

Суд, разрешая дело, применяет непосредственно Конституцию, в частности:

a) когда закрепленные нормой Конституции положения, исходя из ее смысла, не требуют дополнительной регламентации и не содержат указания на возможность ее применения при условии принятия федерального закона, регулирующего права, свободы, обязанности человека и гражданина и другие положения;

б) когда Конституционным Судом Российской Федерации выявлен пробел в правовом регулировании либо, когда пробел образовался в связи с признанием не соответствующими Конституции нормативного правового акта или его отдельных положений с учетом порядка, сроков и особенностей исполнения решения Конституционного Суда Российской Федерации, если они в нем указаны.

Исходя из смысла данной нормы постановления Пленума Верховного суда Российской Федерации, определяется императивность применения нормы Конституции в вопросе обязательности получения основного общего образования на территории Российской Федерации

При этом, в правоприменительной практике не обозначены случаи судебных разбирательств по противоречию в регулировании данной правовой коллизии.

На основания изложенного и следуя словам Пьера Тейяра де Шардена, «рефлексия - то, что отличает человека от животных, благодаря ей человек может не просто знать нечто, но ещё и знать о своём знании», в целях закрепления полученных знаний и отражения сделанных выводов относительно объекта исследования целесообразно подвести итог.

С развитием образовательной сферы социальной политики Российской Федерации и возникновением прецедентов в судебном пространстве правовой системы Российской Федерации, возникновение отношений в вопросе противоречия нормы Федерального закона «Об образовании в Российской Федерации» Конституции, остается вопросом времени.

В целях минимизации правового нигилизма и повышения правовой культуры граждан, отображается необходимость органа исполнительной власти Российской Федерации в сфере просвещения по внесению в Федеральное собрание Российской Федерации проекта нормативного правового акта о внесении изменений в Федеральный закон «Об образовании в Российской Федерации», либо обращения заинтересованных субъектов права в Конституционный суд Российской Федерации с запросом о конституционности определенной выше правовой нормы федерального законодательства Конституции.

Лишь прибегая к решительным мерам, гражданское общество и политическая элита Российской Федерации могут достичь тех поставленных задач и целей, с помощью которых российское образование вернет былую славу эталонного в мировом сообществе. 


\section{Библиографический список}

1. «Конституция Российской Федерации» (принята всенародным голосованием 12.12.1993) (с учетом поправок, внесенных Законами РФ о поправках к Конституции РФ от 30.12.2008 N 6-ФКЗ, от 30.12.2008 N 7-ФК3, от 05.02.2014 N 2-ФКЗ, от 21.07.2014 N 11-ФКЗ)

2. Федеральный закон «Об образовании в Российской Федерации» от 29.12.2012 N 273-Ф3. ст. 2, 66;

3. Постановление Пленума Верховного суда Российской Федерации от 31 октября 1995 года № 8 «О некоторых вопросах применения судами Конституции Российской Федерации при осуществлении правосудия» 